\title{
HUMAN IMPACT ON KARST: THE EXAMPLE OF LUSAKA (ZAMBIA)
}

\author{
Jo DE WAELE ${ }^{1}$ and Roberto FOLLESA ${ }^{1}$
}

\begin{abstract}
Lusaka, the capital of Zambia with over 2,000,000 inhabitants, is built on an extensive plateau composed mainly of schists and dolomitic marbles, constituting a very important aquifer that provides the city with almost half of its drinking water needs. Recent demographic growth, leading to uncontrolled urban expansion, and mismanagement of the water resource and of urban waste has lead, in the past 20 years, to an overexploitation of the aquifer and to a generalised water quality depletion, putting in serious danger the future social and economical development of the capital. This third world city has, for these reasons, become a terrifying example of human impact on a vulnerable karst environment, and if no measures will be taken in the very near future, quality of life in the city will be at serious risk.
\end{abstract}

Keywords: Zambia, karst, hydrogeology, pollution, remediation

\section{Introduction}

Lusaka is the capital of Zambia (ex-Rhodesia) situated on a plateau mainly composed of dolomitic marbles and schists in the centre of the country. This rapidly expanding city has an estimated population of over 2,000,000 people mostly living in uncontrolled settlements without primary services such as water and electricity supply, sewage systems and waste collection. The dolomitic marbles underlying most of the city constitute a karstic aquifer of regional importance, providing almost half of the total amount of water to Lusaka for agricultural, industrial and domestic use, resulting thus in a strategically very important resource for the capital.

The rapid demographic growth has caused an increasing negative impact on the karstic environment and on this aquifer, with uncontrolled human activities (settlements, quarrying, etc.), scattered waste and sewage disposal, groundwater quality and quantity depletion etc.

The Authors give a general overview of the geo-environmental situation of the Lusaka area with special regard to the karst aquifer and some guidelines for the mitigation and the rimediation of its pollution.

1 - University of Cagliari, Geology Department, Via Trentino, 51- 09127 Cagliari (Italy), Tel. + 39-070-6757778 Fax: + 39-070-282236 - e-mail: geoam@unica.it 


\section{Geographical and geological outline}

Lusaka is built on a plateau which stands at an altitude of $1,300 \mathrm{~m}$ a.s.l. to the North and gently drops to 1,200 m a.s.l. towards the East, the South and the West The study area is entirely comprised in the topographical Map of Greater Lusaka of the Republic of Zambia in scale 1:50,000 and is located between latitudes $15^{\circ} 10^{\prime}$ and $15^{\circ} 50^{\prime}$ 'South and longitudes $27^{\circ} 45^{\prime}$ and $28^{\circ} 30^{\prime}$ East.

Natural vegetation is characterised by Miombo savannah-type woodlands, while in the North, along the Ngwerere and Chunga rivers, and to the Southwest, along the road to Chilanga, extensive farmlands and cultivated areas are situated. The natural forest reserves North and South of Lusaka have gradually been cut to leave space for newly growing townships.

The flat morphology of the Lusaka plateau is the result of intense and long during weathering of the outcropping lithologies, resulting in flat schist and carbonate plains with rounded quartzite hills, forming an immense erosion plateau known as the Gondwana and Africa surface (Dixey, 1945).

The Lusaka plateau forms a watershed between the Chumba river, which ends up in the Mwembeshi river to the West, and many smaller rivers which end up into the Chongwe to the Northwest and Kafue rivers to the South.

The Lusaka area is underlain by a thick sequence of Precambrian metasediments which have been intruded by granitic and basic bodies (Simpson et al., 1963). These Precambrian rocks were divided into a mostly granitic Basement complex and the metasediments of the Katanga Supergroup.

The Basement complex crops out to the North and South of Lusaka and are composed of coarse grained quartz-muscovite-biotite schists and sheared quartz-feldsparbiotite gneisses in the North and augen gneisses, feldspathised and foliated schists in the South. The augen gneisses have been dated at 1106+/-19 Ma (Hanson, 1990).

The metasediments, which dominate in the central part of the area and underly the city of Lusaka, are composed, from bottom to top, of Matero Quartzite, Ridgeway Schist and Lusaka Dolomite (Newman \& Matheson, 1966; Thieme, 1984). These last are grouped in the Lusaka Formation, prevalently composed of dolomitic marbles.

From a structural point of view many fracture joints, shears and thrust faults occur especially on the schist-dolomite contact, representing highly permeable areas in which surface water easily reaches the watertable.

Locally upon these ancient rocks alluvial sediments (Quaternary) have been deposited. Furthermore all these rocks are covered with a more or less thick cover of soils, mainly composed of iron-oxide ooliths in a clayey matrix on dolomitic lithologies and sandy sediments on schists, gneisses and granites (Fig. 1)

\section{Current geo-environmental situation}

The population of Lusaka is distributed in many historical compounds and unplanned townships. Recent estimates report that only $32 \%$ of the inhabitants are provided by a sewer service, $43 \%$ use septic tanks while the remaining $25 \%$ have pit 


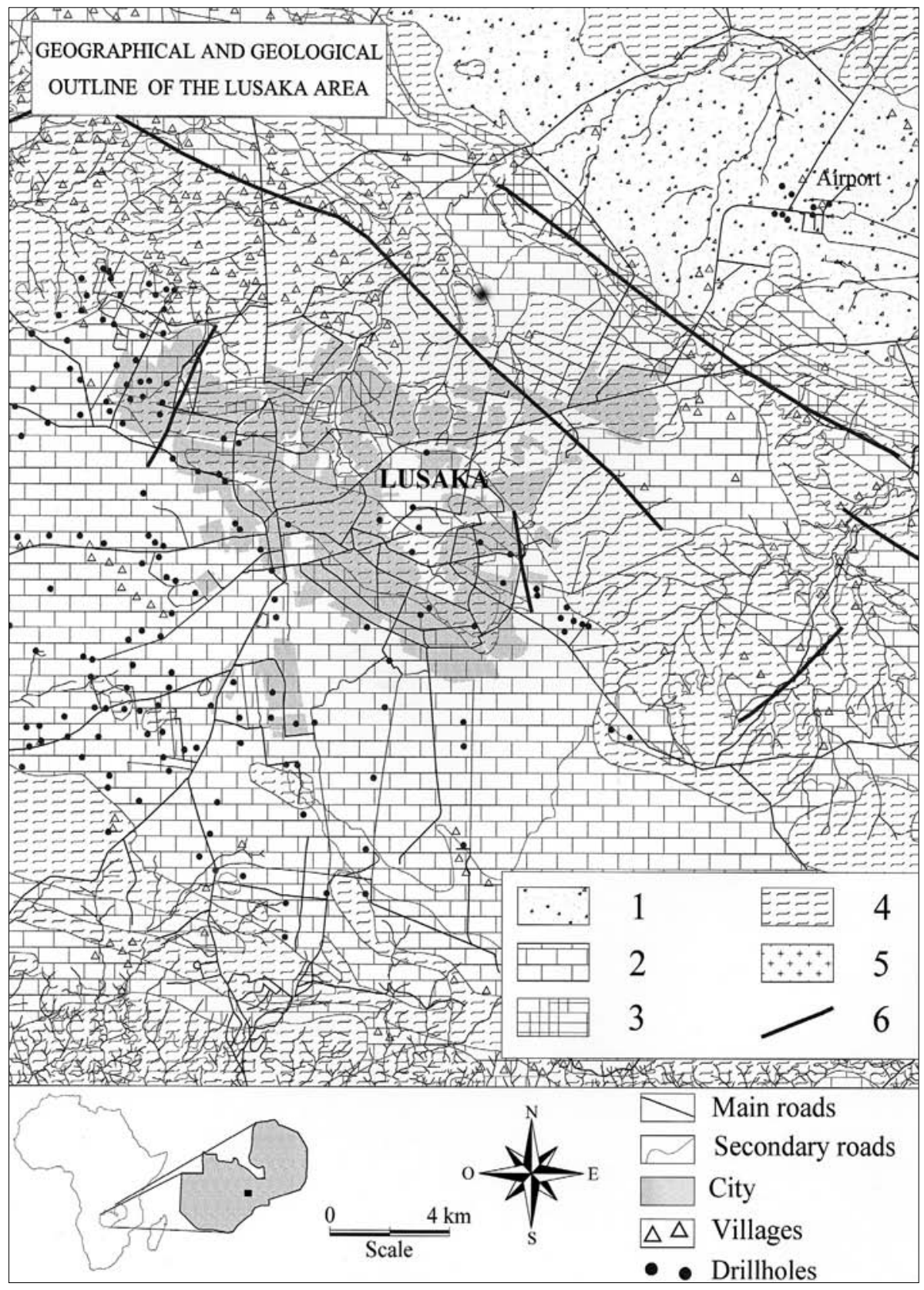

Fig. 1 - Geographical and geological outline of the study area: Quaternary: 1: Old and recent alluvial deposits; Precambrian: 2: Lusaka Dolomite; 3: Matero Quartzite; 4: Ridgeway schist; 5: Granite (modified from De Waele et al., 2002). 
latrines. Especially the unplanned squatter townships are lacking the primary services: there is no electricity and no water in the houses; water is taken from few fountains mainly constructed in the framework of international financial aid programs. Liquid waste and sewage are not collected and are dumped in open channels or left in pit latrines without any waterproofing. The same can be told for solid urban waste which is dumped in a haphazard way in the open spaces between the houses or is sometimes locally collected and brought in illegal waste dumps.

Local water demand is estimated in $450,000 \mathrm{~m}^{3} /$ day: considering a daily consumption per person of 180 litres the domestic water demand is estimated in 360,000 $\mathrm{m}^{3} /$ day, while the remaining $90,000 \mathrm{~m}^{3} /$ day are used by industry. $100,000 \mathrm{~m}^{3} /$ day of water is taken from the Kafue river, at about $40 \mathrm{~km} \mathrm{~S}$ of Lusaka, and is brought to the capital through a mostly external pipeline of $2 \mathrm{~m}$ diameter. At least 350,000 $\mathrm{m}^{3} /$ day is taken from the aquifer, of which $90,000 \mathrm{~m}^{3} /$ day comes from 40 production wells of Lusaka city, leaving not less than $260,000 \mathrm{~m}^{3} /$ day pumped from $3000-4000$ private boreholes (Nyambe \& Maseka, 2000; Nkhuwa, 2000).

For what concerns urban waste, considering a domestic waste production of a little more than ? kg/day/person, Lusaka's population produces about 1,100,000 kg/day of waste material for a yearly production of 400,000 tons. Of all this waste material only $10 \%$ is collected and was brought, until the end of the $20^{\text {th }}$ century, to the only official dump site situated near the compound of Libala, in a flat and open terrain where laterite quarrying was carried out and is still going on. This dumping site, that should have been closed in 1994, is situated in the recharge area of the Lusaka Dolomite aquifer and is now abandoned; recently the Libala compound is urbanising the area with new settlements.

Since 1999 Lusaka's waste is brought in a dump site close to the city of Kafue, located on the flank of a quartzite hill at a distance of more than $30 \mathrm{~km}$ from the capital, with great transport expenses. Waste is approximately composed of $20 \%$ each of plastic and metal cans, $15 \%$ oil sludges, $10 \%$ each of vegetal-paper-rock-glass, $3 \%$ clinical waste and $2 \%$ other types of materials (Nkhuwa, 2000).

\section{Karst around Lusaka}

The plateau on which Lusaka is built is characterised by a flat morphology in which the lowest areas are generally underlain by schists, less resistant to erosion, the intermediate ones are characterised by the outcropping of dolomitic marbles and the few hills, locally named kopjes, are made out of massive marbles, gneisses or quartzites, much more resistant to erosion. Surface drainage is almost exclusively present on the crystalline lithologies or schists, while on the dolomitic marbles water tends to disappear randomly underground along fractured zones normally close to the contact.

Surface karst on the dolomitic marble is hidden by a layer of laterite soil which can attain a thickness of a couple of meters. These laterites are extensively exploited by local people and in the places where this cover has been taken away a well karstified surface is exposed. Extensive rounded karren fields, sculpted on the boundary between laterite and carbonatic rock, are clearly visible and go down up to 4-5 meters 


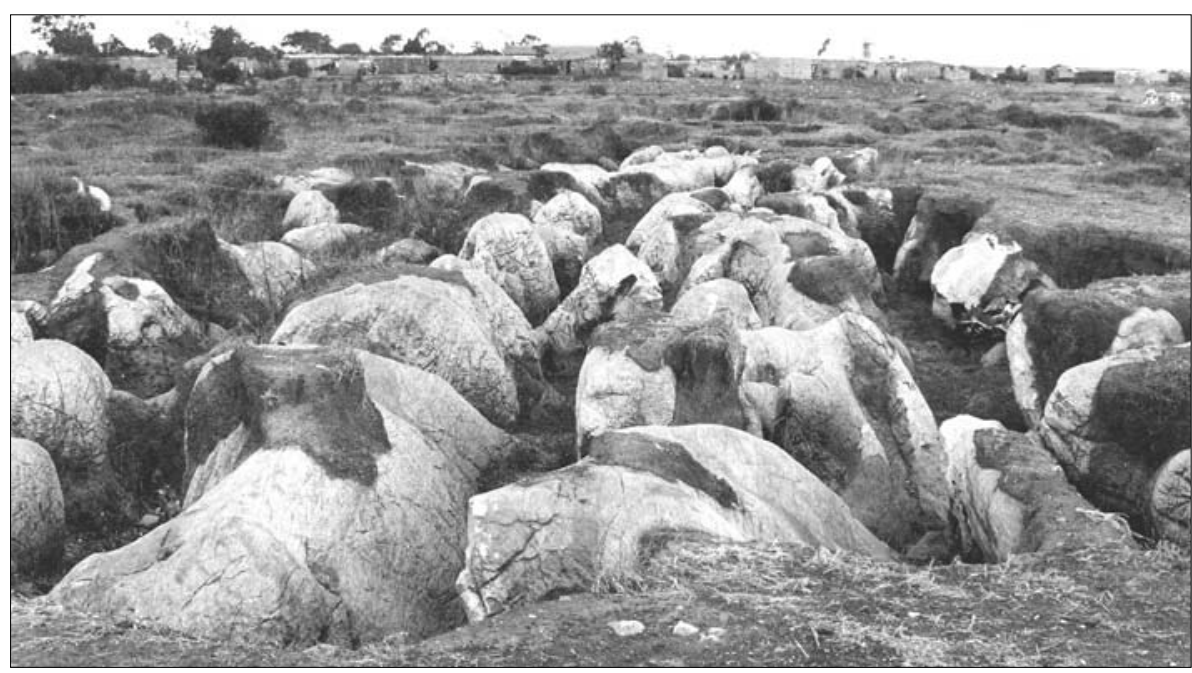

Fig. 2 - Diffuse laterite quarrying all around the capital of Lusaka exposes a rounded karren field oriented along the main fracture directions. These areas, which sometimes are ideal places for illegal waste dumping, are extremely vulnerable places for the pollution of the aquifer.

from the surface (Fig.2). In the absence of the filtering laterite cover these exposed rounded karren fields constitute places in which surface drainage water easily infiltrates and reaches the subterranean aquifer.

Some deep drillholes have demonstrated that the dolomitic marbles of the Lusaka Formation are fractured and karstified up to a depth of at least $100 \mathrm{~m}$, constituting the most important aquifer of central Zambia.

Although these marbles cover a surface of more than 1,600 square $\mathrm{km}$ in the region of Lusaka, only few caves have been reported in literature (Kaiser et al., 1998). The widespread erosion and the extensive laterisation of the region did not allow the preservation of many caves that have been completely destroyed or filled up with sediments. The few caves which are known are all situated on the flank of little hills and anyhow above the medium altitude of the plateau, and represent relics of a relatively ancient karst which inferior parts are completely filled up with laterites and/or sediments.

The most important and best known caves are situated at Leopard's Hill $(60 \mathrm{~km}$ East of Lusaka), near the little village of Chipongwe (30 km South of the capital) and close to Kafue river at Kapongo village (50 km South of Lusaka) (Blondé et al., 2001; Kaiser et al., 1998).

Leopard's Hill cave has three entrances on the flank of the homonymous dolomitic limestone hill, is characterised by an impressive fruit-bat colony, responsible of the thick guano deposit, and is of archaeological interest.

Chipongwe cave, very similar to the Leopard's Hill cave for the presence of a bat colony, a guano deposit and archaeological remains, is characterised by the presence of a subterranean lake corresponding to the local karst aquifer base level (Hansford, 1969).

Near the village of Kapongo two caves are known, until recently exploited for 
their guano deposits. Similarly to the other two caves, here also a big bat colony has produced a thick guano deposit, but these caves are different from the others due to the presence of calcite speleothems.

\section{The Lusaka karstic aquifer}

The calcareous and dolomitic marbles, which have been grouped in the Lusaka Formation, represent a karst aquifer of regional importance that provides almost half of the water to the city of Lusaka.

This karst aquifer is characterised by an epikarstic zone which extends to a depth of $25 \mathrm{~m}$ below the surface, composed of solution channels, rounded karren, solution flutes and -cavities which allow water to descend rapidly to the water table, situated at an average depth ranging from $-2 \mathrm{~m}$ to $-25 \mathrm{~m}$ and lowering year after year due to overexploitation and general diminishing of annual rainfall (Nkhuwa, 2000; Maseka \& Nyambe, 1999; Nyambe \& Maseka, 2000). The base of karstic aquifer is thought to be at $-150 \mathrm{~m}$ and solution cavities have been found at depths of $-65-80 \mathrm{~m}$ and $-125-$ $150 \mathrm{~m}$. The Lusaka dolomitic marble aquifer has an estimated thickness of 15-20 m and an average specific capacity of about $50 \mathrm{~m}^{2} / \mathrm{d}$, representing the best water supply of the city (Simpson et al., 1963). Average borehole yields are between 4-8 1/s, and some drillholes have reached yields of 100 1/s. Underground water flows from SE to NW with branches to the NE and SW, and the highest potentiometric levels (1300 m a.s.l.) have been observed in the Southern Lusaka Forest Reserve which is the main recharge area of the entire karstic aquifer (Maseka \& Nyambe, 1999). In this area the watertable is visible in several quarries (Fig. 3).

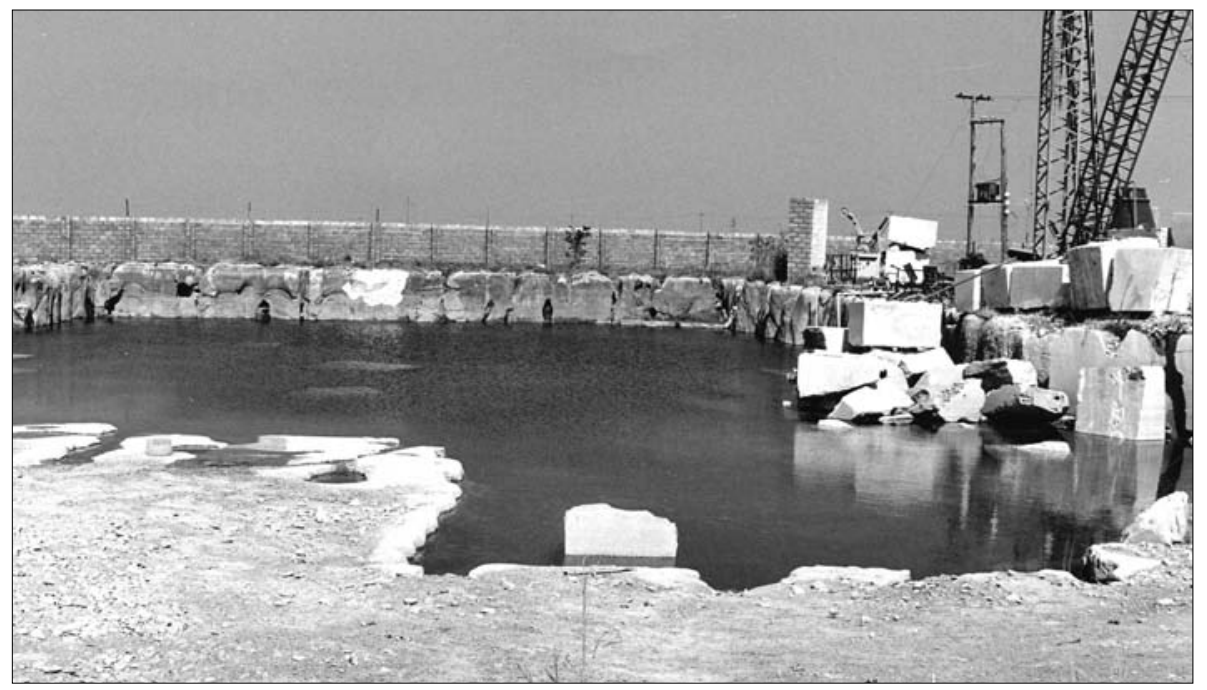

Fig. 3 - Marble quarry East of Lusaka in which the local water table crops out. The excavations expose an intensely karstified marble with solution flutes, rounded karren and phreatic passages in the epikarstic zone. 
According to the latest published data average annual rainfall in Lusaka can be estimated in $714 \mathrm{~mm}, 27 \%$ of which can actually be believed to infiltrate into the aquifer while the remaining $73 \%$ gets lost through evapotranspiration and superficial flowing. Groundwater recharge would therefore be $35,712,000 \mathrm{~m}^{3} /$ year $\left(97,841 \mathrm{~m}^{3} /\right.$ day) (Nyambe \& Maseka, 2000).

In July 2001 nine water samples were taken for analysis and the results are summarised in Table 1. At the sampling site, temperature, $\mathrm{pH}$, conductivity, and ammonium were measured, waters were filtered $(0.4 \mu \mathrm{m}$, Nuclepore 111130), and acidified for metal analyses. Ammonium was determined by a colorimeter kit (Idrimeter Carlo Erba), anions by ion chromatography, and metals by inductively coupled plasma optical emission spectroscopy (ICP-OES, ARL-3520 ${ }^{\circledR}$ ) and inductively coupled plasma mass spectrometry (ICP-MS, ELAN$5000^{\circledR}$ ), while $\mathrm{Hg}$ was determined by ICP-MS after flow injection $\mathrm{Hg}$-vapour or hydride generation (Cidu, 1996).

Water samples show temperatures of $19-24^{\circ} \mathrm{C}$ (air temperature over sampling ranged from 21.1 to $30.8{ }^{\circ} \mathrm{C}$ ), $\mathrm{pH} 7.1-7.8$, conductivity $0.20-0.86 \mathrm{mS} / \mathrm{cm}$ with the lowest conductivity being observed in the shallow groundwater Z9, and the highest in the stream Z6. The main contribution

\begin{tabular}{|c|c|c|c|c|c|c|c|c|c|c|}
\hline & 已 & : & 8 & 8 & 8 & 8 & 28 & 8 & 蒠 & 28 \\
\hline & $0 \overline{\bar{\varepsilon}}$ & 5 & $\frac{6}{0}$ & $\frac{ \pm}{0}$ & 응 & กิ & 5 & d & $\vec{\sigma}$ & $\overline{0}$ \\
\hline & 定 & $\tilde{\nabla}$ & $\tilde{\vec{v}}$ & $\tilde{\nabla}$ & $\overline{0}$ & $\tilde{v}$ & 导 & $\tilde{\nabla}$ & $\tilde{\nabla}$ & E \\
\hline & $\therefore$ & $\mp$ & 导 & I & $\cong$ & r & $\Xi$ & 호 & $\stackrel{2}{2}$ & $\varepsilon$ \\
\hline 8 & 艎 & $\approx$ & $\vec{\nabla}$ & $\vec{\nabla}$ & $\cong$ & $\vec{\nabla}$ & $=$ & $\vec{\nabla}$ & $\underset{i}{\infty}$ & $\bar{E}$ \\
\hline & రั & $\vec{\nabla}$ & $\vec{\nabla}$ & $\vec{\nabla}$ & $\vec{\nabla}$ & $\vec{\nabla}$ & בi & $\tilde{\sigma}$ & ż & $\bar{c}$ \\
\hline$\approx$ & లి & $\begin{array}{c}0 \\
f \\
f\end{array}$ & 요 & 용 & $\overrightarrow{\hat{v}}$ & ‡ & 3 & $\stackrel{\circ}{=}$ & i̊ & a \\
\hline & \pm & $\stackrel{2}{\tilde{v}}$ & $\stackrel{\partial}{\tilde{v}}$ & $\stackrel{2}{\tilde{v}}$ & $\approx$ & $\stackrel{2}{\tilde{\vartheta}}$ & त्र & $\ddot{\partial}$ & ర․ & c \\
\hline & & $\overrightarrow{\vec{\theta}}$ & $\vec{\nabla}$ & $\vec{\nabla}$ & $\overrightarrow{\vec{v}}$ & $\vec{\nabla}$ & $\stackrel{0}{1}$ & $\vec{\nabla}$ & $\vec{\nabla}$ & $\bar{c}$ \\
\hline & & 8 & 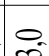 & 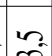 & \& & $\underset{+}{0}$ & 士 & $\approx$ & $\tilde{\check{n}}$ & 7 \\
\hline & च $\bar{g}$ & $=0$ & $\stackrel{\sim}{f}$ & 2 & 8 & $\overline{6}$ & $\approx$ & $\underset{\infty}{\infty}$ & 3 & $y$ \\
\hline & & $\approx$ & $\bar{\nabla}$ & 은 & $\overline{2}$ & $\nexists$ & 8 & 戸 & I & g \\
\hline & & & & & & 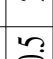 & & & & \\
\hline & & s. & $\vec{v}$ & 8 & $\approx$ & $\theta$ & $\stackrel{\infty}{+}$ & 0 & 1 & 7 \\
\hline & $\ddot{z}$ & $\underset{v}{\vec{v}}$ & 0 & 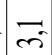 & $\approx$ & $\underset{\sim}{\Xi}$ & $m$ & 电 & 6 & 7 \\
\hline & $\sum^{\infty}$ & స & 으 & 구 & 2 & 士 & 요 & శ్ & a & $\alpha$ \\
\hline & $\tilde{J}$ & $\cong$ & త్ & व & in & กี & $\stackrel{2}{2}$ & 2 & 워 & $\approx$ \\
\hline & 合 & $\approx$ & $\frac{0}{n}$ & 吕 & శ্ & ฉิ & 孛 & f & 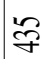 & $\cong$ \\
\hline & 完 & ह⿸厂万ठ & $\sqrt{2}$ & $2 \frac{2}{6}$ & ?ִ & $\pi$ & : & 용 & 5 & 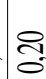 \\
\hline$\cdot$ & 言 & $\cong$ & $\cong$ & $\stackrel{\infty}{\sim}$ & $\because$ & $\because$ & $\because$ & 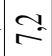 & $\approx$ & 2 \\
\hline & $\leftarrow$ & $a$ & 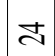 & $a$ & 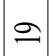 & 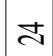 & $a$ & $\approx$ & $\widetilde{\sim}$ & $\approx$ \\
\hline & $£$ & $\overline{\mathrm{d}}$ & $\overline{\vec{\Xi}}$ & $\bar{\Xi}$ & $\mid$ & $\overline{\vec{\mho}}$ & $\begin{array}{l}\text { 胥 } \\
\text { 惫 }\end{array}$ & $\overline{\bar{\mho}}$ & $\bar{\mho}$ & $\bar{\Xi}$ \\
\hline & & & $\mathbb{N}$ & $N$ & $N$ & $\checkmark$ & $\pi$ & $\mathbb{N}$ & 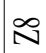 & \\
\hline
\end{tabular}


to the total dissolved solids (TDS) derives from $\mathrm{HCO}_{3}$ and $\mathrm{Ca}$, while $\mathrm{Cl}, \mathrm{SO}_{4}$, $\mathrm{Mg}, \mathrm{Na}$ and $\mathrm{K}$ are always subordinate. Both $\mathrm{HCO}_{3}$ and $\mathrm{Ca}$ concentrations increase with increasing TDS. The $\mathrm{Ca}-\mathrm{HCO}_{3}$ dominant composition reflects a prevalent water circulation in the carbonate rocks of Lusaka. The stream waters (Z4 and Z6) show $\mathrm{NH}_{4}$ above $1 \mathrm{mg} / \mathrm{l}$ (see Table 1); a phosphate concentration of $4 \mathrm{mg} / \mathrm{l}$ is only observed in the stream water Z6 other samples being below detection limit. The high concentrations of ammonium and phosphate in solution clearly reflect the impact of uncontrolled urban wastes and sewages on the water system.

The concentration of Sr varies between 26 and $300 \mu \mathrm{g} / \mathrm{l}$ and the highest concentration appears associated with the highest concentrations of $\mathrm{Na}$ and $\mathrm{SO}_{4}$. Highly toxic elements such as $\mathrm{As}, \mathrm{Pb}$ and $\mathrm{Cd}$ show very low concentrations, i.e. always below $0.5,0.7,0.1 \mu \mathrm{g} / \mathrm{l}$, respectively. In contrast, concentrations of mercury in four water samples $(\mathrm{Z6}, \mathrm{Z} 4, \mathrm{Z} 8, \mathrm{Z1})$ are 1.1-13 $\mu \mathrm{g} / \mathrm{l}$; these values exceed the guideline of $1 \mu \mathrm{g} / \mathrm{l}$ proposed by the World Health Organisation (WHO, 1993) for drinking water and are most probably related to the uncontrolled urban wastes and sewages as the common source of pollution.

More worrying is the average level of nitrate-nitrogen which is $15-40 \mathrm{mg} / \mathrm{l}$ (exceeding the World Health Organisation limit of $10 \mathrm{mg} / \mathrm{l}$ ) and ammonia which has been found in 4 water samples taken directly from the aquifer, both demonstrating pollution of the underground water resource by decomposing organic matter, mostly deriving from pit latrines and leaching septic tanks.

The overexploitation of this aquifer, together with the superficial pollution (quarries, waste dumps, sewage water, etc.), are putting in danger this resource of fundamental importance for the sustaining and the development of the capital.

\section{Guidelines for the protection and the management of Lusaka's groundwater resources}

In the past decades groundwater of the karstic aquifer has been characterised by a quantity and quality depletion due to over-pumping (besides the 40 production wells of Lusaka city, between 3000 and 4000 private boreholes extract large quantities of water) and to the compromised environmental situation (pollution from waste dumps, rubbish pits, septic tanks and pit latrines).

In Fig. 4 has been represented the land use map of the area of Lusaka.

Once groundwater is polluted, restoring to drinking water standards can be very expensive or even impossible. Furthermore, many contaminated sites are the source of pollution for many years.

The epikarstic zone of the Lusaka dolomitic marble Formation is overlain by a more or less thick layer of laterite that covers a well developed subcutaneous karstified surface. This laterite, composed of oolithes embedded in a clayey matrix acts as a shield for polluting agents to penetrate directly into the aquifer. Once this protecting layer is taken away, by excavations and laterite quarrying, the pollution 


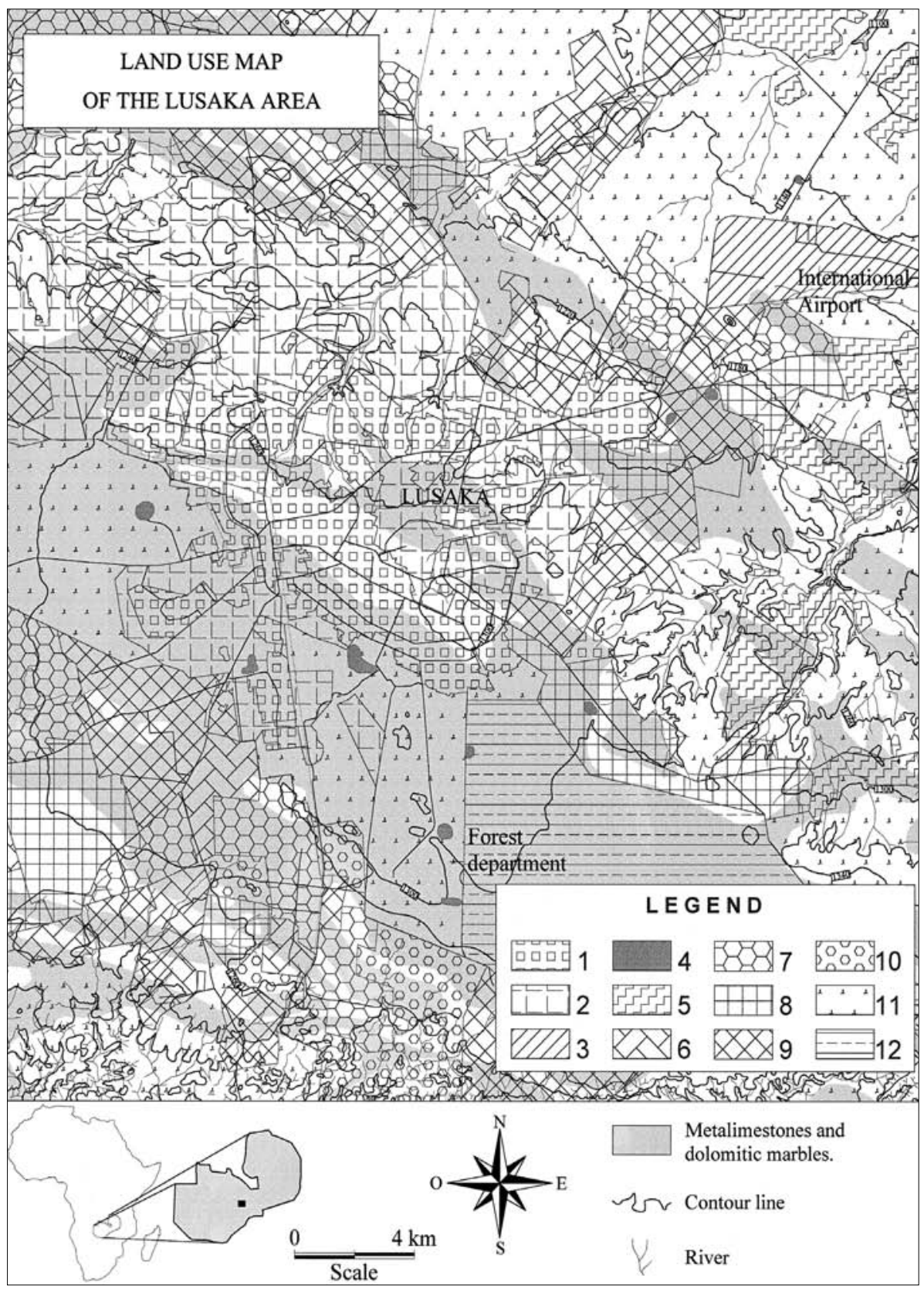

Fig. 4 - Land use map of the area of Lusaka: 1: urbanised area; 2: small villages; 3: Airport; 4: Marble quarries; 5: Medium sized farmlands; 6: Irrigated farmlands; 7: Big cultivated farmlands; 8: Small farms; 9: urbanised areas with kitchen-gardens; 10: Savanna with scattered trees; 11:Savanna; 12: Forest and woodland. 
has its free way, furthermore enhanced during rainy season when the water table surfaces in the open excavated karren fields (Fig. 5).

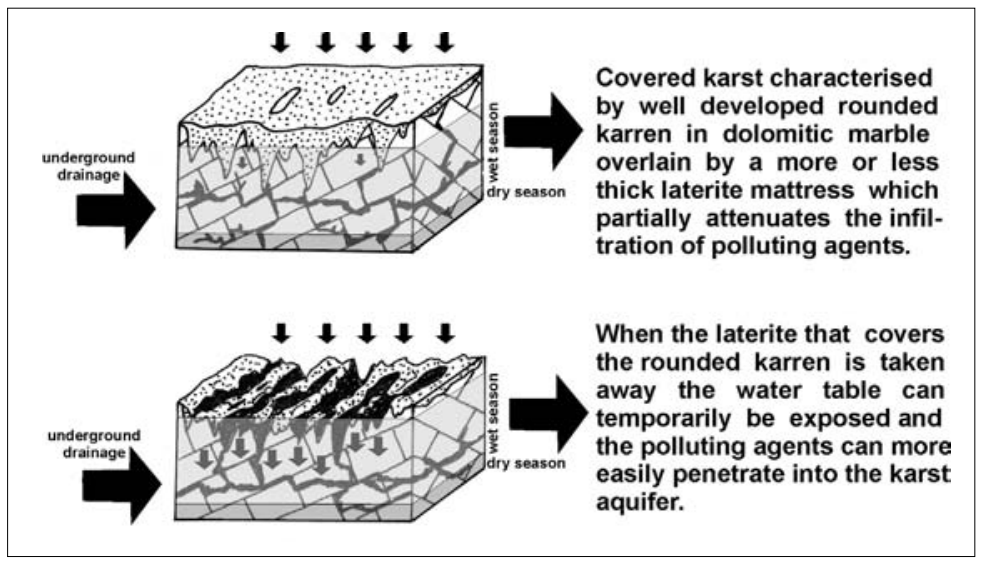

Fig. 5 - Aquifer vulnerability in relation with the laterite cover.

Many human activities in Lusaka make the karstic aquifer extremely vulnerable to pollution (Fig.6).

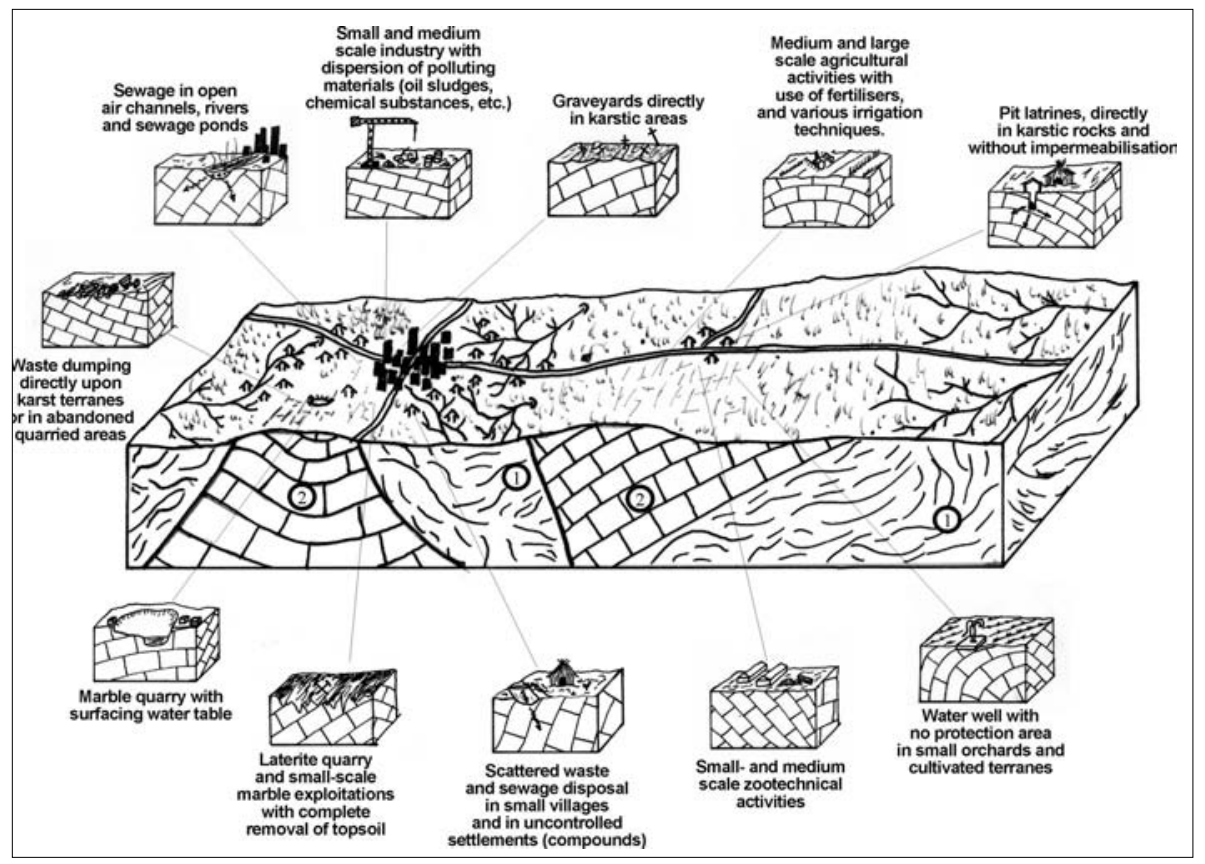

Fig. 6 - Block diagram schematising the various polluting activities in the Lusaka area: 1. Clastic metasediments; 2. Marbles of the Lusaka formation. 
To prevent further worsening of the already partly compromised situation of the ground water, it has become extremely urgent to start a policy program of protection of this fundamental resource for the future development of Lusaka.

Among the actions to undertake the control of water extraction by making an inventory of private boreholes and controlling their water abstraction rates and their influence on the aquifer (pumping tests, nearby drillholes etc.) is one of the most important. Furthermore, the protection of the recharge areas (Lusaka forest reserve and the major fractured areas on the contact between schist and dolomite) and the zones at less than $50 \mathrm{~m}$ from boreholes, where human activities have to be restricted and compatible with the necessity of preserving the quality of the groundwater, is another important action that should be undertaken very soon. Combined with these actions, the control of groundwater quality, directed especially towards microbiological content, nitrate and ammonia, phosphates, salinity and periodically also heavy metals, by monitoring wells in the aquifer, would be more than advisable. At last the individuation of new groundwater resources around Lusaka, outside the already over exploited well field, is recommended.

In order to prevent pollution from uncontrolled waste dumps it has become extremely urgent to open new waste tipping sites outside the recharge areas of the aquifer (De Waele et al., 2000; De Waele et al., 2002).

If in the following few years these measures will not be taken, Lusaka will most probably face a water supply crisis due to quantity and quality depletion of the actual exploited aquifer, with great problems for the economical and social development of the city.

\section{Conclusions}

Most of Lusaka's inhabitants are living in unplanned townships without primary services such as water and electricity supply, sewage systems and waste collection. The demographic evolution of the past 20 years has caused an increasing negative impact on the karst environment, with uncontrolled human activities (settlements, quarrying, etc.), scattered waste and sewage disposal, groundwater quality and quantity depletion etc.

As water quality and quantity is a prerogative for a healthy and sustainable society, and karst environments are much more vulnerable to industrial and urban impacts (Hötzl, 1999), this preliminary geo-environmental study has outlined and offered some guidelines which should be taken into account by the local and national authorities.

The main problem is the waste management, and the closure or reclamation of existing waste dumps, the upgrading of existing waste dumps to landfills, the establishment of new urban waste landfills and plants in geo-environmentally suitable sites and the education for public awareness and training through local waste management projects in the compounds to prevent and reduce haphazard waste dumping are action which should be undertaken in the very near future.

Also the enlarging of sewerage drainage systems to all compounds, the enforcing 
of control on groundwater abstraction and pollution, and demarcation of zones of respect at existing drill holes, the provision of the city with new water supplies from outside the Lusaka well-field are other urgent actions that would resolve some of the existing ground water pollution problems.

At last environmental education should be increasing to all, in school and to the population.

It is clear that groundwater management has still a long way to go in Zambia and the low development of these subjects is unfortunately strictly related to the lack of financing, of skilled manpower and of consciousness that preventing pollution of groundwater and of soil is of vital importance for the future of Lusaka and of entire Zambia.

The Authors hope, anyway, that the local authorities will start considering these problems of primordial interest, starting international aid programs, for the sake and the benefit of the whole population.

\section{Acknowledgements}

This study has been carried out with the financial aid of the Sardinian Regional Government in the framework of the Project "Anthropogenic and natural processes in the Lusaka area leading to environmental degradation and their possible mitigation" (Responsible Prof. Felice Di Gregorio) (Regional Law n43/1990). Special thanks to Prof. Rosa Cidu for the geochemical analysis of the water samples and to Mr. Simasiku Simasiku of the School of Mines of University of Zambia for accompanying us on the karst of Lusaka.

\section{REFERENCES}

BLONDE P., DE WAELE J., GRAFITTI G. 2001. Indagine geologico-ambientale e faunistica in alcune grotte dello Zambia. Anthèo, Boll. Gr. Spel.-Arch. Giovanni Spano Cagliari 5: 28-33.

CIDU R. 1996. Comparison of ICP-MS and ICP-OES in the determination of trace elements in water. Atomic Spectroscopy 17 (4): 155-162.

DE WAELE B., NKEMBA S., NGOMA P. 2000. Geographic Information System and Remote Sensing based preliminary study to target areas suitable to develop as solid waste tipping site in the Lusaka area. Unpublished report, School of Mines, University of Zambia: 11 p.

DE WAELE J., NYAMBE I.A., DI GREGORIO A., DI GREGORIO F., SIMASIKU S. , FOLLESA R., NKEMBA S. 2002. Urban waste landfill planning and management of groundwater resources in developing countries: the example of Lusaka (Zambia). Proceedings of the $19^{\text {th }}$ Colloquium of African Geology, El Jadida 19-22 march 2002 (in print).

DIXEY F. 1945. The geomorphology of Northern Rhodesia. Transactions of the Geological Society of South Africa 47: 9-45. 
HANSFORD B. 1969. Chipongwe cave, Zambia. Wessex Cave Club Journal 10(123): 311312.

HANSON R.E. 1990. A review of the geochronological data for the proterozoic of Central and Southern Africa. Geol. Soc. Zambia. Journ. Appl. Earth. Sc. 4(1): 6-19.

HOTZL H. 1999. Industrial and urban produced impacts: 81-184. In: DREW, D, HOTZL H. (Eds.) - Karst hydrogeology and human activities. Impacts, consequences and implications, Balkema Rotterdam.

KAISER T.M., SEIFFERT C., TRULUCK T. 1998. The speleological potential of limestone karst in Zambia (Central-Africa) - a reconnaissance survey. Cave and Karst Science 25(1): 23-28.

MASEKA C., NYAMBE I.A. 1999. Lusaka's groundwater resources at risk: 75-90. In: JOHN DEVLIN (Editor) - Environmental Capacity Enhancement Project (ECEP). Canadian International Development Agency.

NEWMAN D., MATHESON G.D. 1966. The economic potential of limestones near Lusaka. Econ. Rep. Geol. Surv. Zambia 10: 1-26.

NKHUWA D.C.W. 2000. Management of groundwater resources in Lusaka, Zambia, and expectations for the future: 993-998. In: SILILO ET AL. (Eds.) - Groundwater: Past Achievements and Future Challenges, Balkema Rotterdam.

NYAMBE I.A., MASEKA C. 2000. Groundwater pollution, landuse and environmental impacts on Lusaka aquifer: 803-808. In: SILILO ET AL. (Eds.) - Groundwater: Past Achievements and Future Challenges, Balkema Rotterdam.

SIMPSON J.G., DRYSDALL A.R., LAMBERT H.H.J. 1963. The geology and groundwater resources of the Lusaka area, Explanation of Degree sheet 1528, NW Quarter. Geol. Rep. North. Rhod. Geol. Surv. 16: 1-59.

THIEME J.G. 1984. The geological map of the Lusaka area (1:250,000). Geol. Map. Geol. Surv. Zambia, Sheet $\mathrm{N}^{\circ}$ SD-35-15.

WORLD HEALTH ORGANISATION. 1993. Guidelines for drinking water quality. World Health Organisation, Geneva, 1993.

Received: 1 february 2003

Accepted: 18 march 2003 